\title{
Human Leukocytic Pyrogen Induces Release of Specific Granule Contents from Human Neutrophils
}

\author{
Mark S. Klempner, Charles A. Dinarello, and John I. Gallin, Laboratory of \\ Clinical Investigation, National Institute of Allergy and Infectious Diseases, \\ National Institutes of Health, Bethesda, Maryland 20014
}

\begin{abstract}
A B S T RACT The ability of highly purified human leukocytic pyrogen (LP) to induce neutrophil lysosomal protein release is described. Human peripheral blood neutrophils isolated by Ficoll-Hypaque and dextran sedimentation were exposed to purified human LP. The specific granule-associated proteins, lysozyme and lactoferrin were selectively released, whereas primary granule ( $\beta$-glucuronidase) and cytoplasmic (lactic dehydrogenase) enzyme markers were not. Optimum release was observed after $45 \mathrm{~min}$ in the presence of $\mathrm{Ca}^{++}$and $\mathrm{Mg}^{++}$. Cytochalasin B (5 $\left.\mu \mathrm{g} / \mathrm{ml}\right)$ had no effect on LP-induced lysosomal enzyme release. Since the pyrogenicity of LP is dependent on prostaglandin synthesis, the effect of two potent inhibitors of prostaglandin synthesis on lysozyme release was studied. Both indomethacin and naproxen failed to inhibit specific granule protein release. These observations suggest that the concommitance of fever, elevated serum or urine lysozyme and hypoferremia may, in part, be explained by the interaction of LP and peripheral blood neutrophils.
\end{abstract}

\section{INTRODUCTION}

Fever, whether present in inflammatory or infectious diseases, is mediated by a small, molecular weight (15,000 daltons) protein called leukocytic pyrogen $(\mathrm{LP})^{1}(1)$. In addition to its ability to elevate temperature, LP has been shown to acutely reduce serum iron, and this hypoferremia is dependent on the presence of neutrophils because it does not occur in neutropenic animals (2). Lactoferrin, an iron-binding protein found in neutrophil-specific granules is thought to be the necessary granulocyte factor responsible for hypoferremia (3). Another specific granule constituent, lysozyme, is

Received for publication 14 September 1977 and in revised form 16 December 1977.

'Abbreviations used in this paper: HBSS, Hanks' balanced salt solution; LP, leukocyte pyrogen; RPD, rabbit pyrogenic dose. markedly reduced in neutrophils obtained from patients with acute febrile infections (4). In addition, the constellation of fever, reduced serum iron, hypoferremic anemia, and elevated serum or urine lysozyme has been demonstrated in several inflammatory diseases (5-7). These observations suggested to us that $\mathrm{LP}$, in addition to mediating fever, might directly interact with the neutrophil and result in release of neutrophil granule constituents.

In this report, we demonstrate that small amounts ( $\leqslant 10 \mathrm{nM}$ ) of highly purified human LP cause selective release of specific granule contents from neutrophils. Degranulation takes place in the absence of phagocytosis, adherence to surfaces, or cytochalasin B. This is the first report of a physiologic substance which releases lysosomal contents without other cellular manipulation and these observations may, in part, provide the basis for hypoferremia and elevated serum or urine lysozyme in several febrile inflammatory diseases.

\section{METHODS}

Preparation of neutrophils. Heparinized venous blood was collected from healthy adult volunteers and centrifuged on Ficoll-Hypaque gradients followed by dextran sedimentation (8). Erythrocytes were lysed with hypotonic saline and the resulting leukocyte suspension was washed twice in Hanks' balanced salt solution (HBSS, National Institutes of Health media unit) containing $1.0 \mathrm{mM} \mathrm{CaCl} 2$ and $0.5 \mathrm{mM}$ $\mathrm{MgCl}_{2}$. Leukocytes obtained in this manner contained $96-$ 98\% neutrophils.

Preparation of human LP. Human LP was prepared from mononuclear cells as described previously (9). Crude supernates containing LP were concentrated in autoclaved dialysis tubing in front of a high-speed fan. Volumes were reduced $1 / 20$ and dialyzed against phosphate-buffered saline with $0.02 \%$ sodium azide. Concentrated LP was placed over an immunoadsorbant column containing rabbit anti-human LP antibody attached to CNBr-activated Sepharose. LP was eluted from this material in citric acid buffer, pH 3.2 (10), neutralized with $0.1 \mathrm{M} \mathrm{NaOH}$, and stored in $0.02 \% \mathrm{Na}$ azide. LP eluted from the anti-LP immunoadsorbant was concentrated and chromatographed over Sephadex G-50) (fine) (Pharmacia Fine Chemicals Inc., Piscataway, N. J.) $(165 \times 5.6 \mathrm{~cm})$ at $4^{\circ} \mathrm{C}$ in phosphate-buffered saline with $0.02 \% \mathrm{Na}$ azide. The 
15,000 mol wt LP peak was isolated, dialyzed against $\mathrm{H}_{2} \mathrm{O}$, and lyophilized. This material gave a single staining band on $7.5 \%$ polyacrylamide gels in $0.1 \%$ sodium dodecyl sulfate.

As described, further purification of human LP was carried out using ${ }^{125}$ I-labeled LP $(11,12)$. A small quantity of this


added to unlabeled LP isolated from Sephadex G-50. This material was chromatographed over G-15 followed by DEAE ion-exchange and, in each case, the radioactivity peak was used to indicate purified unlabeled LP. Since biologic activity of LP decreased significantly during the ion-exchange step, $0.1 \%$ albumin was added to each collection tube to prevent nonspecific adsorbtion. Recovery of biologic activity was between 1 and $2 \%$ of the starting concentrated crude LP.

Rabbit pyrogen assay. Details concerning housing, training, and temperature recordings have been reported elsewhere (13). To determine the number of pyrogenic doses in preparations of human LP, a two-point dose-response was employed using six rabbits as described elsewhere $(10,13)$. For the present study, peak fever occurring in rabbits between 0.6 and $1.0^{\circ} \mathrm{C}$ was considered a rabbit pyrogenic dose (RPD) and in a previous report has been estimated to contain $50 \mathrm{ng}$ or less of the purified LP protein (12). Based on the 15,000dalton mol wt of human LP, $1 \mathrm{RPD} / \mathrm{ml}$ is $\leq 30 \mathrm{nM}$.

Incubation conditions. Neutrophils were adjusted to 1.0 $\times 10^{7}$ or $5 \times 10^{7}$ cells $/ \mathrm{ml}$ in HBSS. For some experiments, the concentrations of $\mathrm{CaCl}_{2}$ and $\mathrm{MgCl}_{2}$ were varied to examine the divalent cation effect on lysosomal protein release. Neutrophil suspensions were then incubated for $45 \mathrm{~min}$ at $37^{\circ} \mathrm{C}$ in a shaking water bath in media alone or in the presence of LP. LP was dialyzed against $\mathrm{HBSS}$ or $\mathrm{H}_{2} \mathrm{O}$ to remove sodium azide. For inhibitor or enhancement experiments, cells were preincubated with the pharmacologic agent or media alone followed by the usual 45-min incubation period. After incubation, cells were centrifuged at $400 \mathrm{~g}$ for $10 \mathrm{~min}$ at $4^{\circ} \mathrm{C}$ and the supernates were collected.

Enzyme determinations. Lysozyme was determined by measuring the rate of lysis of Micrococcus lysodeikticus (Worthington Biochemical Corp., Freehold, N. J.) at pH 6.2 according to a turbidometric method (14). $\beta$-Glucuronidase was assayed by measuring the release of phenolphthalein from its $\beta$-glucuronate (Sigma Chemical Co., St. Louis, Mo.) after $6 \mathrm{~h}$ of incubation at $\mathrm{pH} 4.5$ (15). Lactic dehydrogenase was



FIGURE 1 Isoelectric focusing of ${ }^{125}$ I-labeled human LP. $1 \%$ ampholine (3-10) and $4.5 \%$ acrylamide. Gel lengths were 2.5 $\times 100 \mathrm{~mm}$. Constant voltage, $200 \mathrm{~V}$, was applied for $18 \mathrm{~h}$ at $4^{\circ} \mathrm{C}$. Gels were cut every $2 \mathrm{~mm}$ and the radioactivity and $\mathrm{pH}$ were measured on each fraction. assayed by measuring the consumption of $\beta$-nicotinamideadenine dinucleotide (NADPH) during the conversion of pyruvate to lactate (16). Enzyme activity for lysosyme, $\beta$ glucuronidase and lactic dehydrogenase is expressed as the percent of total activity in a freeze-thawed lysate of $1.0 \times 10^{7}$ neutrophils in $1.0 \mathrm{ml}$ of incubation media. Lactoferrin was quantitated by radial immunodiffusion in agarose gels (17). For these studies, neutrophils were suspended in HBSS at $5 \times 10^{7}$ cells $/ \mathrm{ml}$ and incubated with $\mathrm{LP}(10 \mathrm{RPD} / \mathrm{ml})$ as previously described. After incubation, supernates and freezethawed cell lysates were extracted in $1 \mathrm{M} \mathrm{NaCl}$ at $4^{\circ} \mathrm{C}$ overnight (18). The specimens were then centrifuged for $30 \mathrm{~min}$ at $20,000 \mathrm{~g} 4^{\circ} \mathrm{C}$ to remove insoluble material. Radial immunodiffusion plates were prepared using commercially obtained rabbit antisera to human lactoferrin (Behring Diagnostics, Somerville, N. J.). Purified human colostral lactoferrin (Calbiochem, San Diego, Calif.) and neutrophil extracts at various concentrations were used as the immunodiffusion standards. Using these methods, the minimum concentration of detectable lactoferrin was $20 \mu \mathrm{g} / \mathrm{ml}$. Results are expressed as either micrograms equivalent of human colostral lactoferrin or the percent of total lactoferrin released.

Prostaglandin assay. $\mathrm{PGF}_{2 \alpha}$ was determined by radioimmunoassay (kindly performed by Dr. Michael Kaliner) (19). 100- $\mu$ l experimental samples were incubated with $6,000 \mathrm{cpm}$ $\left[{ }^{3} \mathrm{H}\right] \mathrm{PGF}_{2 \alpha}$ and $50 \mu \mathrm{l}$ of rabbit anti-prostaglandin in a final volume of $450 \mu \mathrm{l}$ trizma $(0.012 \%), \mathrm{NaCl}(0.083 \%)$ and gelatin $(0.1 \%)$, pH 7.4 at $4^{\circ} \mathrm{C}$ for $12-16 \mathrm{~h}$. The bound $\left[{ }^{3} \mathrm{H}\right] \mathrm{PGF}_{2 \alpha}$ was separated from unbound $\left.{ }^{3} \mathrm{H}\right]$ prostaglandin by adding $1.0 \mathrm{ml}$ of iced charcoal $(0.25 \%)$ dextran $(0.025 \%)$ in Tris- $\mathrm{NaCl}$ buffer and incubating at $4^{\circ} \mathrm{C}$ for $20 \mathrm{~min}$. After centrifugation $(200 \mathrm{~g}$ for $10 \mathrm{~min}$ ), the supernate was placed into scintillation vials with $10 \mathrm{ml}$ Aquasol (American Cyanamid Co. Pearl River, N. Y.) and the radioactivity was determined in an LS-350 (Beckman Instruments, Inc., Fullerton, Calif.). The results are expressed as micrograms per $10^{7}$ neutrophils.

Statistics. Student's $t$ test was used to compare the means and standard errors for significance except where otherwise noted.

\section{RESULTS}

Enzyme release. Semipurified preparations of human LP which had been eluted from anti-LP immunoadsorbants followed by gel filtration on Sephadex G-50 contained no detectable lysozyme, $\beta$-glucuronidase, lactic dehydrogenase, or lactoferrin. Over a wide concentration range, LP caused selective extracellular release of lysozyme with little or no release of $\beta$-glucuronidase (Fig. 2). Furthermore, there was consistently $<4 \%$ of total lactic dehydrogenase activity in the incubation media, indicating that lysozyme release was not a result of cell death. Significant release of lysozyme was observed at LP concentrations of $1 \mathrm{RPD} / \mathrm{ml}$. Maximal enzyme release occurred by $20 \mathrm{RPD} / \mathrm{ml}$ and higher LP concentrations did not result in additional lysozyme release. By light microscopy, neutrophils exposed to 10 $\mathrm{RPD} / \mathrm{ml}$, which had released $\cong 20 \%$ of total lysozyme, did not appear vacuolated and there was no gross change in cytoplasmic granularity. Heating these preparations of $\mathrm{LP}$ at $80^{\circ} \mathrm{C}$ for $15 \mathrm{~min}$ or precipitation in the presence of $\mathrm{NaCl}$ during lyophilization, procedures which destroy the pyrogenicity of human LP, destroyed 


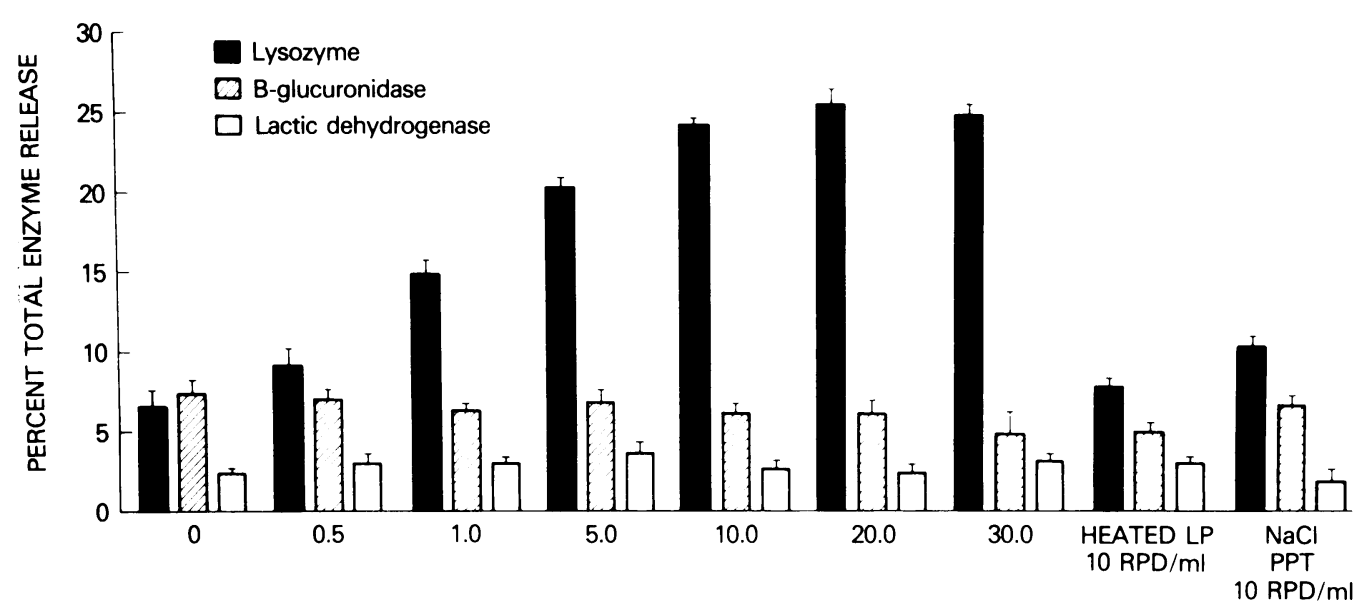

LP CONCENTRATION (RPD/ml)

Figure 2 Dose-response curve of LP-induced enzyme release. Results are the mean $\pm S E M$ of three separate experiments.

its ability to release lysozyme. Furthermore, large pyrogenic doses of endotoxin $(300 \mu \mathrm{g} / \mathrm{ml})$ (Escherichia coli endotoxin, Difco Laboratories, Detroit, Mich.) had no effect on lysosomal release under these conditions. Therefore, the ability of these semipurified preparations of human LP to release lysozyme was not due to contamination by endotoxin. In addition, preparations of LP were negative in the Limulus amebocyte lysate test (20).

To ascertain that the LP molecule was responsible for releasing lysozyme in the above experiments, further purification methods were employed. 500 RPD were purified using immunoadsorbance, gel filtration over G-50, G-15, and DEAE ion-exchange as described in Methods. Human serum albumin $(0.1 \%)$ was added to the collection tubes from the final ion-exchange column to protect the molecule against nonspecific losses. Despite such measures, only five RPI) of purified LP were recovered. When this preparation was divided into two samples and incubated with neutrophils, the quantity of lysosyme release was $16.5 \pm(0.2 \%$ which is comparable to the amount of lysozyme released by $2.5 \mathrm{RPD} / \mathrm{ml}$ (Fig. 2). Human serum albumin, adjusted to the same protein concentration (at $280 \mathrm{~nm}$ ) served as a control and did not release lysozyme. Because of the low recovery $(1 \%)$ of pyrogenic doses encountered during purification of LP, subsequent experiments were carried out using semipurified preparations.

The kinetics of LP-induced lysozyme release in two separate experiments are shown in Fig. 3. By 1 min, $9.8 \pm 1.0 \%$ of total lysozyme was released. Neutrophils incubated in buffer released $<3 \%$ of lysozyme at this time (not shown). A $50 \%$ maximal response was reached between 5 and $15 \mathrm{~min}$ and $<5 \%$ additional enzyme was released over the next $30 \mathrm{~min}$ of incubation.

Lactoferrin release is shown in Table $I$. A freezethawed lysate of $5 \times 10^{7}$ polymorphonuclear leukocytes, extracted as described, contained $276 \pm 14 \mu \mathrm{g}$ of lactoferrin. When neutrophils were incubated with LP at 10

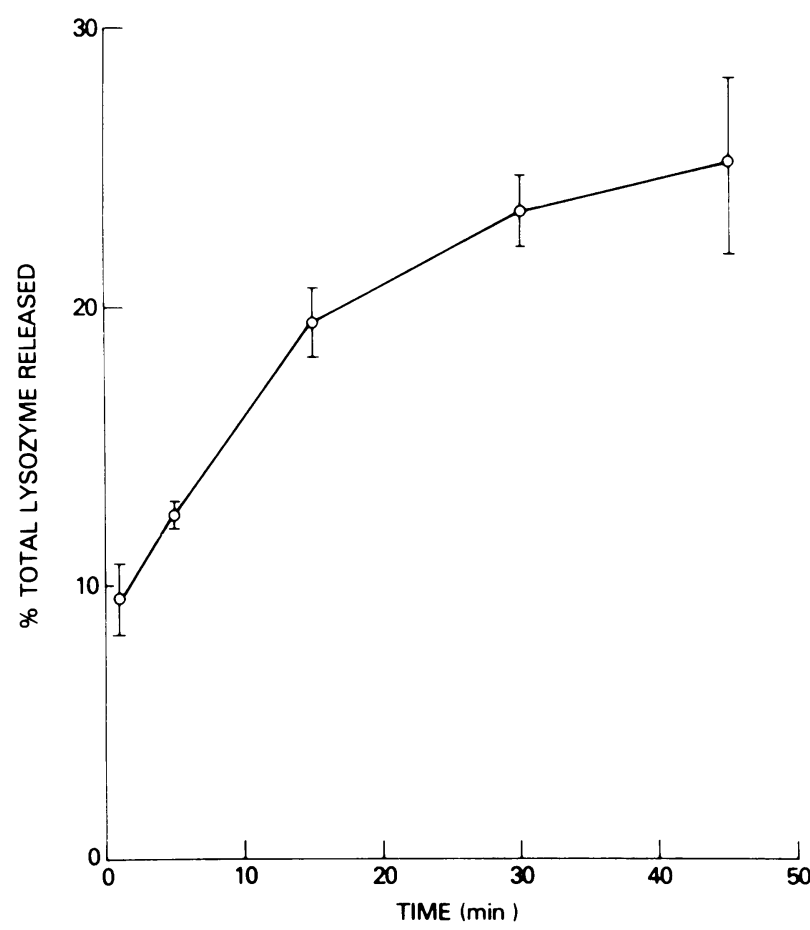

Figure 3 Kinetics of LP-induced lysozyme release. Results are the mean \pm SEM of two separate experiments. 
TABLE I

LP-Induced Neutrophil Lactoferrin Release

\begin{tabular}{ccc}
\hline Preparation & Lactoferrin & Total released \\
\hline & $\mu g / m l$ & $\%$ \\
Whole cell lysate* & & - \\
Exp 1 & 263 & - \\
Exp 2 & 290 & \\
Media from neutrophils & & \\
incubated in: & & 0 \\
Buffer & $<20$ & 0 \\
Exp 1 & $<20$ & \\
Exp 2 & & 23.5 \\
LP & 62 & 36.2 \\
Exp 1 & 105 & \\
Exp 2 & & \\
\hline
\end{tabular}

* Neutrophils were at $5 \times 10^{7}$ cells $/ \mathrm{ml}$.

$\mathrm{RPD} / \mathrm{ml}, 29.8 \pm 6.3 \%$ of the total neutrophil lactoferrin content was released into the media. Media from cells incubated in buffer alone contained no detectable lactoferrin. LP-induced lactoferrin release was unaffected by the presence of normal $A B$ serum in the incubation mixture.

Dicalent cation effect on LP-induced enzyme release. Several investigators have demonstrated the divalent cation requirement for optimal lysosomal enzyme release induced by phagocytic and pharmocologic stimuli $(21,22)$. Therefore, we studied the ability of LP to induce enzyme release in the absence of $\mathrm{Ca}, \mathrm{Mg}$, or both. Results are shown in Table II. LP, in the absence of either Ca or $\mathrm{Mg}$, caused significant lysozyme release when compared to the buffer. Maximum release was observed when $\mathrm{Ca}$ and $\mathrm{Mg}$ were present. With either $\mathrm{Ca}$ or $\mathrm{Mg}$ alone, an intermediate yet significant re-

TABLE II

Effect of Calcium and Magnesium on LP-Induced Lysozyme Release

\begin{tabular}{cllccc}
\hline & \multicolumn{2}{c}{ Cation } & & \\
\cline { 2 - 4 } $\mathrm{LP}$ & $\mathrm{Ca}^{+{ }^{*}}$ & $\mathrm{Mg}^{++}$ & & Lysozyme & $P^{*}$ \\
\hline $5 \mathrm{RPD} / m l$ & $m M$ & $m M$ & & \% release & \\
0 & 0 & 0 & $5.5 \pm 0.8(5) \ddagger$ & - \\
+ & 0 & 0 & $11.8 \pm 0.8(5)$ & $<0.001$ \\
+ & 1.5 & 0 & $14.6 \pm 1.0(2)$ & $<0.01$ \\
+ & 2.5 & 0 & $14.6 \pm 0.3(1)$ & $<0.02$ \\
+ & 0 & 1.0 & $13.8 \pm 0.5(2)$ & $<0.01$ \\
+ & 0 & 2.5 & $14.7 \pm 0.1(1)$ & $<0.02$ \\
+ & 1.5 & 1.0 & $21.9 \pm 1.2(5)$ & $<0.001$ \\
\hline
\end{tabular}

* Significance level of difference compared to percent enzyme release in the absence of $\mathrm{LP}, \mathrm{Ca}^{++}$, and $\mathrm{Mg}^{++}$.

$\$$ Mean \pm SEM percent lysozyme release (Methods). Number of different experiments in parentheses. For one experiment, mean $\pm \mathrm{SEM}$ of triplicate samples are shown. sponse was observed. Nevertheless, enzyme release with either divalent cation alone was not simply additive and the two cations together act synergistically (four sample paired $t$ test $P<0.05$ ). $\beta$-Glucuronidase release remained $<8 \%$ in all these experiments (data not shown).

Failure to effect LP-induced enzyme release by indomethacin, naproxen, or cytochalasin B. LP is thought to produce fever by inducing local prostaglandin synthesis in the hypothalmus (23). We therefore investigated the effect of two potent prostaglandin inhibitors on enzyme release induced by LP. Neutrophils were preincubated for $15 \mathrm{~min}$ with various concentrations of indomethacin $(1-100 \mu \mathrm{M})$ or naproxen at $100 \mu \mathrm{M}$. After preincubation, LP was added at 5 or $20 \mathrm{RPD} / \mathrm{ml}$ and the incubation continued for an additional $45 \mathrm{~min}$. As shown in Fig. 4, there was no significant effect on enzyme release by either agent. Even on the steep portion of the dose-response curve $(5 \mathrm{RPD} / \mathrm{ml})$ no inhibitory effect could be demonstrated. To insure that these agents inhibited prostaglandin synthesis, neutrophils $\left(1 \times 10^{7} / \mathrm{ml}\right.$ in HBSS $)$ were preincubated with indomethacin $\left(1\right.$ or $100 \mu \mathrm{M}$ ) or buffer at $37^{\circ} \mathrm{C}$ for $15 \mathrm{~min}$. Arachadonic acid (10 $\mu \mathrm{g} / \mathrm{ml}$, Sigma Chemical Co.) was then added and the incubation continued for $15 \mathrm{~min}$. Supernates were collected and assayed for prostaglan-

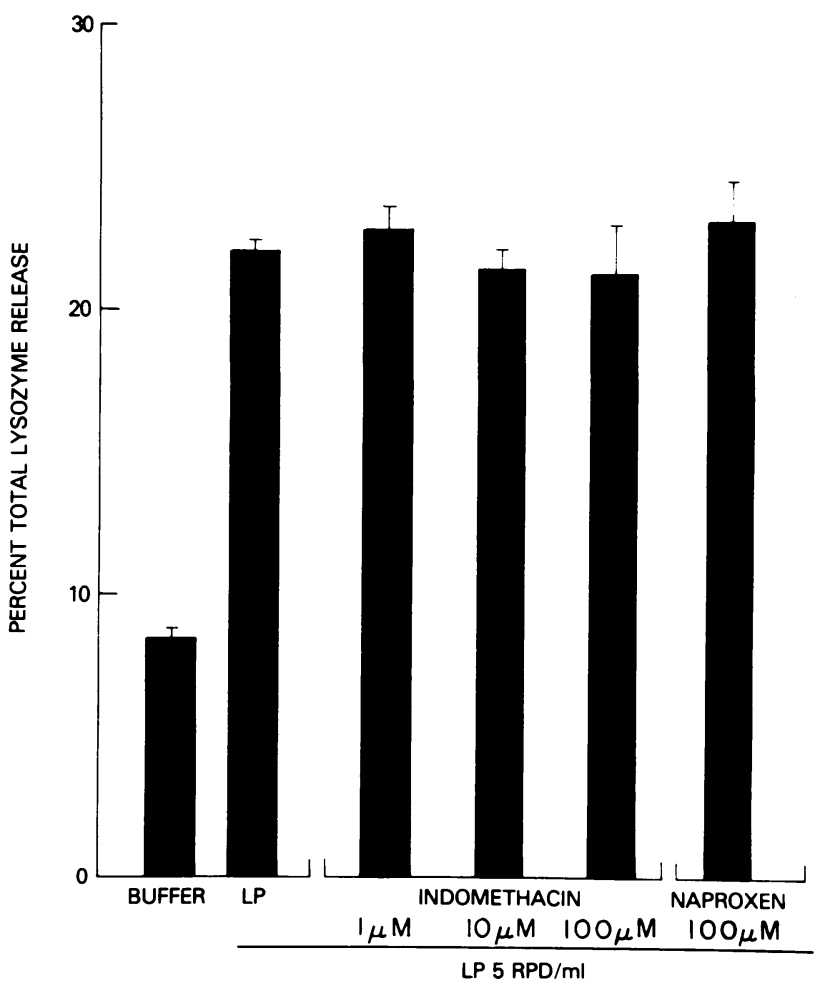

FIGURE 4 Effect of indomethacin and naproxen on LPinduced lysozyme release. Results are the mean $\pm S E M$ of three separate experiments. 
$\operatorname{din} F_{2 \alpha}$. Neutrophils preincubated in buffer and followed by arachadonic acid, produced $193.9 \pm 24.1 \mu \mathrm{g}$ $\mathrm{PGF}_{2 \alpha} / 10^{7}$ neutrophils. Cells exposed to indomethacin at 100 and $1 \mu \mathrm{M}$ before addition of arachadonic acid produced $20.1 \pm 2.8$ and $54.2 \pm 13.0 \mu \mathrm{g} / 10^{7}$ neutrophils, respectively.

Cytochalasin B has been shown by several investigators to facilitate neutrophil enzyme release when cells are exposed to a variety of soluble and particulate stimulants (24). To determine if cytochalasin B caused a similar enhancement of enzyme release when LP was the stimulus, neutrophils were preincubated with cytochalasin B $(5 \mu \mathrm{g} / \mathrm{ml})$ for $10 \mathrm{~min}$. After preincubation $\mathrm{LP}(5 \mathrm{RPD} / \mathrm{ml})$ was added and the incubation continued for $45 \mathrm{~min}$. In three separate experiments, cells in buffer or cytochalasin B without LP released 8.2 \pm 1.4 and $7.3 \pm 0.6 \%$ total lysozyme, respectively $(P$ $>0.05)$. Similarly, in the presence of LP there was no enhancement of lysozyme release with cytochalasin B $(20.1 \pm 1.2 \%$ for $L P$ in buffer vs. $21.2 \pm 1.4 \%$ for $L P$ after cytochalasin $\mathrm{B}, P>0.05)$. $\beta$-Glucuronidase release was also unaffected by cytochalasin B (not shown).

\section{DISCUSSION}

The results of this study demonstrate that a biologically produced human protein, LP, is capable of inducing lysosomal protein release in the absence of phagocytosis, adherence, or cytochalasin B treatment. Other nanaturally occurring serum substances which induce degranulation, such as chemotactic factors, all require perturbation of the neutrophil membrane with cytochalasin $\mathrm{B}$ or adherence to a filter to result in secretion $(25,26)$. Thus, LP represents a naturally occurring small molecular weight protein which can initiate release of specific granule contents from cells in suspension without other perturbation of the cell membrane.

The selectivity for the release of specific granule contents is in keeping with several previous observations that these proteins are more accessible for extracellular release. Studies by Wright and Malawista (27) have shown that under conditions of phagocytosis, lysozyme release was easily demonstrated, whereas certain acid hydrolases associated with peroxidase-positive granules were only minimally released. Lefell and Spitznagel (28) have made similar observations when the degranulating stimulus was immune complex. More recently, selective mobilization of specific granule associated enzymes has been shown with the pharmacologic agents concanavalin $\mathrm{A}$, phorbol myristate acetate, and ionophore A23187 (29-32, 22). In this regard, it is of particular interest that LP follows a similar pattern of selective release of specific granule contents including a requirement for calcium and magnesium for optimal release. The extracellular release of lyso- zyme and lactoferrin in the absence of $\beta$-glucuronidase provides strong evidence that the enzyme-mobilizing effect of LP is primarily on specific granules (33). Furthermore, assaying for $\beta$-glucuronidase during our kinetic studies failed to show significant release of this enzyme even at early time points (not shown). Because recovery of LP from the purification procedure is low $(1 \%)$, it was not possible to assess the effect of higher concentrations on enzyme release. As is the case with ionophore A23187, it is possible that the selectivity for release of specific granule contents might be abolished at greater LP concentrations (32). The lack of an inhibitory effect of indomethacin and naproxen suggests that the LP-induced release is independent of de novo prostaglandin synthesis.

Our in vitro observation that LP is a sufficient stimulus to induce neutrophil specific granule protein release when neutrophils are in suspension may have direct clinical relevance. Acute hypoferremia has been shown to occur in both man and animals after the injection of bacterial endotoxin and to accompany a variety of inflammatory diseases $(34,35,6)$. Even apyrogenic doses of endotoxin are able to produce hypoferremia in man, and the lowering of serum iron corresponds to accumulation of iron in reticuloendothelial cells (6). Similarly, intravenous injection of LP also results in acute hypoferremia (36). Moreover, LPinduced hypoferremia is dependent on neutrophils since it does not occur in neutropenic animals (2) and the factor in neutrophils responsible for lowering of serum iron has been shown to be lactoferrin (3). This glycoprotein, which exists in the neutrophil in the ironfree state (apolactoferrin), avidly binds serum iron, lowers serum iron in a dose-dependent fashion, and after the injection of ${ }^{59} \mathrm{Fe}$ has been shown to accumulate in the saturated state $\left({ }^{59} \mathrm{Fe}\right.$-lactoferrin) in the reticuloendothelial system (3).

Our observations provide a possible explanation for the intermediate step of apolactoferrin release from neutrophils in inflammatory states. In addition, since apolactoferrin is capable of removing $\mathrm{Fe}$ from transferrin- $\mathrm{Fe}_{2}$ under conditions found in inflammatory sites (e.g. acidic $\mathrm{pH}$ ) and $\mathrm{Fe}$-lactoferrin is preferentially cleared from the circulation (3), the equilibrium reaction:

Transferrin- $\mathrm{Fe}_{2}+$ apolactoferrin

$$
\rightleftarrows \text { apotransferrin + lactoferrin- } \mathrm{Fe}_{2},
$$

is constantly shifted to the right. The clinical observation that the hypoferremic hypochromic anemia accompanying inflammation is generally unresponsive to $\mathrm{Fe}$ therapy is not surprising since even small amounts of released apolactoferrin would favor accumulation of $\mathrm{Fe}$-lactoferrin in the reticuloendothelial system and thereby reduce the amount of iron available for hematopoiesis. Whether other sub- 
stances accompanying acute inflammation are also able to induce neutrophil apolactoferrin release remains to be determined.

The kinetic factors responsible for elevated serum lysozyme in inflammatory and myeloproliferative disorders have been extensively investigated. It is well established that renal clearance accounts for the majority of lysozyme elimination. In anephric patients, for example, lysozyme clearance is only $15 \%$ of the rate found in normals (37). In regard to production and release, two major factors have been defined that relate to serum lysozyme: (a) the synthesis and release of lysozyme from leukocytes and $(b)$ the total size of the granulocyte and monocyte pools. In studies by Bodel et al. (38), the lysozyme secretory rate by monocytes from patients with sarcordosis has been shown to be significantly greater than controls and to directly correlate with serum lysozyme levels. Furthermore, these monocytes produce excessive LP in response to endotoxin. Hansen and Andersen (4) have demonstrated that neutrophils isolated from patients with acute bacterial infections contained $50 \%$ less lysozyme than control neutrophils. To account for this finding, these authors suggested that bacterial infection suppressed neutrophil lysozyme synthesis. However, in preliminary studies, we have observed that after a single intravenous injection of bacterial endotoxin into two normal volunteers, mature neutrophils isolated from peripheral blood contained significantly less total lysozyme at $4 \mathrm{~h}$ than at 0 or $24 \mathrm{~h}(27.6 \pm 0.2,23.6 \pm 0.4$, and $29.2 \pm 0.5$ $\mu \mathrm{g} / 5 \times 10^{6}$ neutrophils at 0,4 , and $24 \mathrm{~h}$, respectively, $P<0.02$ comparing the 4 -h lysozyme content to 0 and $24 \mathrm{~h}$ ). Thus, our in vitro and in vivo data suggest that the reduced neutrophil lysozyme content may reflect, at least in part, neutrophil secretion in response to pyrogen.

In myeloproliferative disorders, the size of the granulocyte and monocyte pools has been repeatedly shown to correlate with serum lysozyme (39). In both man and animals, the nadir of granulocytes in druginduced leukopenia corresponds to the nadir of serum lysozyme. Similarly, the highest serum lysozyme levels are observed during marrow hyperplasia with increased granulocyte and monocyte pools. It is interesting to note that LP has an effect on granulocyte turnover. Kampschmidt and Upchurch (40) have shown that repeated injections of LP results in progressive increase in peripheral blood leukocytes. Moreover, in bone marrow culture, LP dramatically stimulated colony formation. Since LP has multiple effects on factors known to effect serum lysozyme, our observations of LP-induced lysozyme release may relate to only a portion of elevated serum lysozyme in inflammatory and myeloproliferative disorders.

The demonstration that a biologic substance induces selective release of neutrophil specific granule con- tents which may be important in a number of inflammatory diseases provides new areas for assessing the clinical importance of both LP and neutrophil secretory products in the pathophysiology of inflammation.

\section{REFERENCES}

1. Dinarello, C. A., and S. M. Wolff. 1976. Exogenous and endogenous pyrogens. In Brain Dysfunction in Infantile Febrile Convulsions. M. A. Brazier and F. Coceni, editors. Raven Press, New York. 117-128.

2. Kampschmidt, R. F., and H. F. Upchurch. 1969. Lowering of plasma iron concentration in the rat with leukocyte extracts. Am. J. Physiol. 217: 1287-1291.

3. Van Snick, J. L., P. L. Masson, and J. F. Heremans. 1974. The involvement of lactoferrin in the hyposideremia of acute inflammation. J. Exp. Med. 140: 1068-1084.

4. Hansen, N. E., and V. Andersen. 1973. Lysozyme activity in human neutrophilic granulocytes. Br.J. Haematol. 24: $613-623$.

5. Perillie, P. E., K. Khan, and S. C. Finch. 1973. Serum lysozyme in pulmonary tuberculosis. Am. J. Med.Sci. 265: 297-302.

6. Cartwright, G. E. 1966. The anemia of chronic disorders. Semin. Hematol. 3: 351-375.

7. Pascule, R. S., J. B. L. Gee, and S. C. Finch. 1973. Usefullness of serum lysozyme measurement in diagnosis and evaluation of sarcoidosis. N. Engl. J. Med. 287: 10741076.

8. Böyum, A. 1968. Isolation of mononuclear cells and granulocytes from human blood. Isolation of mononuclear cells by one centrifugation and of granulocytes by combining centrifugation and sedimentation at $1 \mathrm{~g}$. Scand. J. Clin. Lab. Invest. Suppl. 97: 77-89.

9. Dinarello, C. A., N. P. Goldin, and S. M. Wolff. 1974. Demonstration and characterization of two distinct human leukocytic pyrogens. J. Exp. Med. 139: 1369-1381.

10. Dinarello, C. A., L. Renfer, and S. M. Wolff. 1977. Production of antibody against human leukocytic pyrogen. J. Clin. Invest. 60: 465-472.

11. Dinarello, C. A., and S. M. Wolff. 1977. Partial purification of human leukocytic pyrogen. Inflammation. 2: 179-189.

12. Dinarello, C. A., L. Renfer, and S. M. Wolff. 1977. Human leukocytic pyrogen: purification and development of a radioimmunoassay. Proc. Natl. Acad. Sci. U. S. A. 74: 4624-4627.

13. Wolff, S. M., J. H. Mulholland, and S. B. Ward. 1965. Quantitative aspects of the pyrogenic response of rabbits to endotoxin. J. Lab. Clin. Med. 65: 268-276.

14. Litwack, G. 1955. Photometric determination of lysozyme activity. Proc. Soc. Exp. Biol. Med. 89: 401-403.

15. Talalay, P., W. H. Fishman, and C. Huggins. 1946. Chromagenic substrates. II. Phenolphthalein glucuronic acid as substrate for the assay of glucuronidase activity. J. Biol. Chem. 166: 757-772.

16. Bergmeyer, H. U., editor. 1963. In Methods in enzymatic analysis. Academic Press Inc., New York. 737-739.

17. Mancini, G., A. O. Carbonara, and J. F. Heremans. 1965. Immunochemical quantitation of antigens by single radial immunodiffusion. Immunochemistry. 2: 235-254.

18. Masson, P. L., J. F. Heremans, and E. Schonne. 1969. Lactoferrin, an iron binding protein in neutrophilic leukocytes. J. Exp. Med. 130: 643-658.

19. Jaffe, B. M., J. W. Smith, W. T. Newton, and C. W. Parker. 1971. Radioimmunoassay for prostaglandins. Science (Wash. D. C.). 171: 494-496.

20. Elin, R. J., and S. M. Wolff. 1973. Non-specificity of the 
limulus amebocyte lysate test: positive reactions with polynucleotides and proteins. J. Infect. Dis. 128: 349352.

21. Goldstein, I. M., G. Weissmann, P. B. Dunham, and R Soberman. 1975. The role of calcium in the secretion of enzymes by human polymorphonuclear leukocytes. In Calcium Transport in Contraction and Secretion. E. Carafuli, editor. North-Holland Publishing Co., Amsterdam. $185-193$.

22. Goldstein, I. M., S. T. Hoffstein, and G. Weissmann. 1975. Influence of divalent cations upon complement-mediated enzyme release from human polymorphonuclear leukocytes. J. Immunol. 115: 665-670.

23. Milton, A. S., and S. Wendlandt. 1970. A possible role for prostaglandin $\mathrm{E}_{1}$ as a modulator for temperature regulation in the central nervous system of the cat. J. Physiol. (Lond.). 217: 33-34P.

24. Zurier, R. B., S. Hoffstein, and G. Weissmann. 1973. Cytochalasin B: Effect on lysosomal enzyme release from human leukocytes. Proc. Natl. Acad. Sci. U.S. A. 70: 844848 .

25. Goldstein, I. M., S. Hoffstein, J. I. Gallin, and G. Weissmann. 1973. Mechanisms of lysosomal enzyme release from human leukocytes: Microtubule assembly and membrane fusion induced by a component of complement. Proc. Natl. Acad. Sci. U. S. A. 70: 2916-2920.

26. Becker, E. L., H. J. Showell, P. M. Henson, and L. S. Hsu. 1974. The ability of chemotactic factors to induce lysosomal enzyme release. I. The characteristics of the release, the importance of surfaces and the relation of enzyme release to chemotactic responsiveness. $J$. Immunol. 12: 2047-2054.

27. Wright, D. G., and S. E. Malawista. 1972. The mobilization and extracellular release of granular enzymes from human leukocytes during phagocytosis. J. Cell Biol. 53: $788-797$.

28. Lefell, M. S., and J. K. Spitznagel. 1974. Intracellular and extracellular degranulation of human polymorphonuclear azurophil and specific granules induced by immune complexes. Infect. Immun. 10: 1241-1249.

29. Hoffstein, S., R. Soberman, I. Goldstein, and G. Weissmann. 1976. Concanavalin A induces microtubule assembly and specific granule discharge in human polymorphonuclear leukocytes. J. Cell Biol. 68: 781-787.
30. Goldstein, I. M., S. T. Hoffstein, and G. Weissmann. 1975 Mechanisms of lysosomal enzyme release from human polymorphonuclear leukocytes: effects of phorbol myristate acetate. J. Cell Biol. 66: 647-652.

31. White, J. A., and R. D. Estensen. 1974. Selective labilization of specific granules in polymorphonuclear leukocytes by phorbol myristate acetate. Am. J. Pathol. 75: 45-54.

32. Wright, D. G., D. A. Bralove, and J. I. Gallin. 1977. The differential mobilization of human neutrophil granules. Effects of phorbal myristate acetate and ionophore A23187. Am. J. Pathol. 87: 273-284.

33. Spitznagel, J. K., F. G. Dalldorf, M. S. Lefell, J. D. Folds, I. R. H. Walsh, M. H. Cooney, and L. E. Martin. 1974 Character of azurophil and specific granules purified from human polymorphonuclear leukocytes. Lab. Invest. 30 . 774-785.

34. Ban, A., L. Koscar, J. Kacsko, P. Demeny, J. Csongar, and B. Siro. 1962. Die wirkung eines bakeriellen pyrogenspyrexal- auf das serumeisen. Dtsch. Arch. Klin. Med. 208: $4.5-52$.

35. Kampschmidt, R. F., and H. F. Upchurch. 1962. Effects of bacterial endotoxin on plasma iron. Proc. Soc. Exp. Biol. Med. 110: 191-193.

36. Merriman, C. R., L. A. Pulliam, and R. F. Kampschmidt. 1977. Comparison of leukocytic pyrogen and leukocytic endogeneous mediator. Proc. Soc. Exp. Biol. Med. 154: 224-227.

37. Hensen, N. B., H. Karle, and V. Andersen. 1974. Production and elimination of plasma lysozyme. In Lysozyme. E. F. Osserman, R. E. Canfield, and S. Beychok, editors. Academic Press Inc., New York. 307-319.

38. Bodel, P. T., P. T. Major, and J. B. Gee. 1976. Sarcoidosis: enhanced secretion of endogenous pyrogen and lysozyme by peripheral blood monocytes. Clin. Res. 24: 587A (Abstr.)

39. Finch, S. C., O. Castro, M. E. Lippman, J. A. Donadio, and P. E. Perillie. 1974. Lysozyme in leukopathic states. In Lysozyme. E. F. Osserman, R. E. Canfield, and S. Beychok, editors. Academic Press, Inc., New York. 335345.

40. Kampschmidt, R. F., and H. F. Upchurch. 1977. Possible involvement of leukocytic endogenous mediator in granulopoesis. Proc. Soc. Exp. Biol. Med. 155: 89-93. 